\title{
Étude des décors de stucs du haut Moyen Âge
}

\section{Christian Sapin}

\section{(2) OpenEdition}

\section{Journals}

\section{Édition électronique}

URL : https://journals.openedition.org/cem/3332

DOI : $10.4000 /$ cem.3332

ISSN : 1954-3093

\section{Éditeur}

Centre d'études médiévales Saint-Germain d'Auxerre

\section{Édition imprimée}

Date de publication : 15 août 2003

ISSN : 1623-5770

\section{Référence électronique}

Christian Sapin, "Étude des décors de stucs du haut Moyen Âge », Bulletin du centre d'études médiévales d'Auxerre | BUCEMA [En ligne], 7 | 2003, mis en ligne le 05 décembre 2007, consulté le 22 septembre 2022. URL : http://journals.openedition.org/cem/3332 ; DOI : https://doi.org/10.4000/cem. 3332

Ce document a été généré automatiquement le 22 septembre 2022.

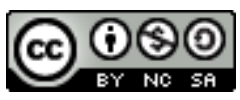

Creative Commons - Attribution - Pas d'Utilisation Commerciale - Partage dans les Mêmes Conditions 4.0 International - CC BY-NC-SA 4.0

https://creativecommons.org/licenses/by-nc-sa/4.0/ 


\title{
Étude des décors de stucs du haut Moyen Âge
}

\author{
Christian Sapin
}

Amorcée depuis trois ans, l'étude d'un ensemble de stucs découvert sur le site de Vouneuil près de Poitiers a été l'occasion de relancer ${ }^{1}$ les recherches sur ce type de décor peu conservé, du moins en France. Avec Bénédicte Palazzo-Bertholon du CESCM de Poitiers et Gilles Fèvre, dessinateur au CEM, nous avons pu reconstituer une série d'arcatures et de personnages qui appartiennent à un ensemble exceptionnel proche des grands décors ravennates. Leur exécution, plus ancienne que l'époque carolingienne à laquelle on les avait attribués jusqu'à présent, nous a incité à proposer en septembre 2004 une exposition, une publication et un colloque ${ }^{2}$ qui permettra de faire le point. L'exposition aura pour ambition de restituer à un large public l'essentiel des connaissances acquises dans ce domaine méconnu, rarement abordé, à travers les découvertes les plus intéressantes effectuées en Europe. Elle permettra de situer le décor de stuc, à mi-chemin entre sculpture et peinture, dans les grands courants artistiques du Moyen Âge, en abordant son origine, ses techniques, son évolution. Cet événement sera l'occasion de réunir, pour la première fois, des ensembles quasiment inédits, récemment découverts ou étudiés. L'exposition circulera à travers l'Europe jusqu'en 2006. 


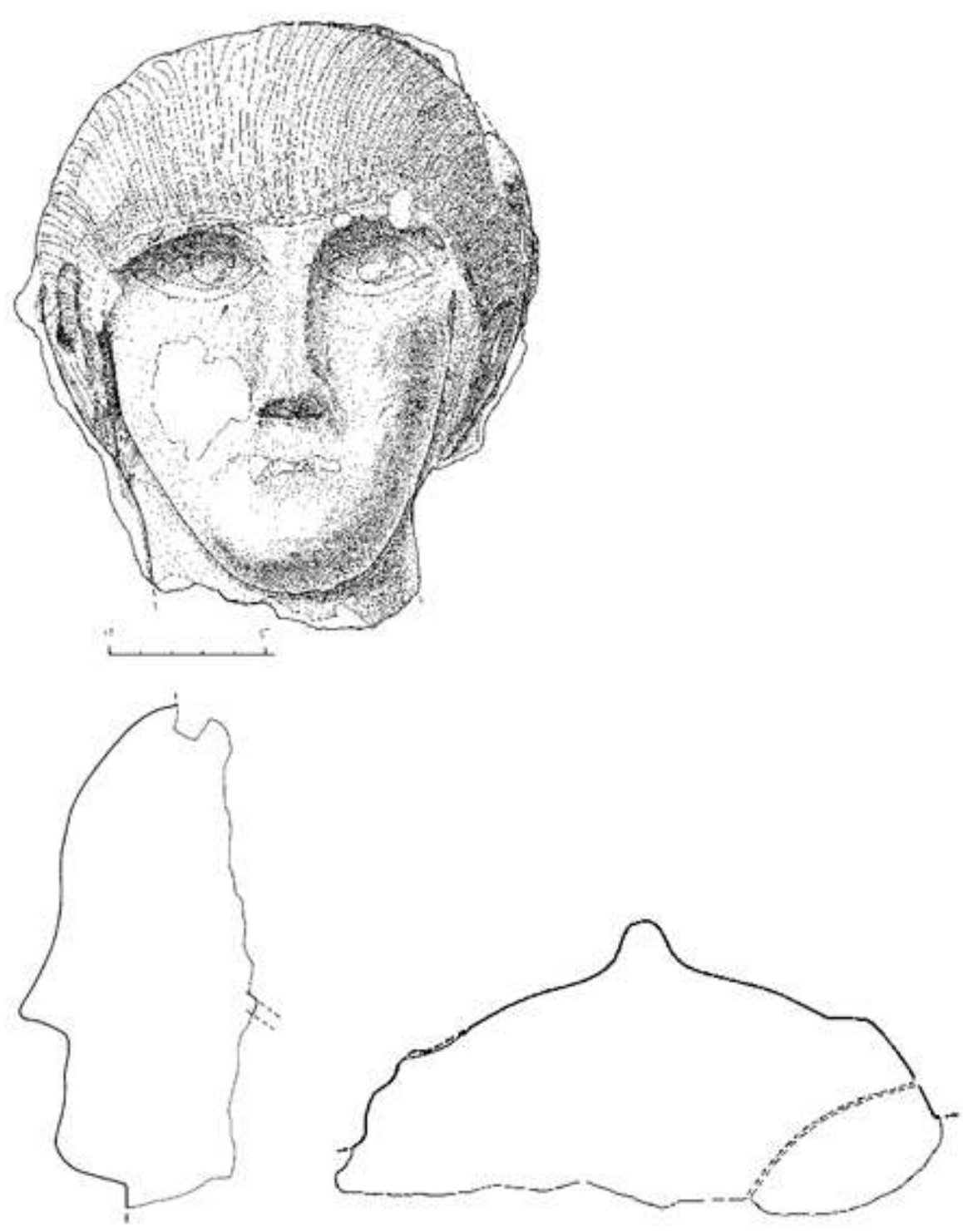

Vouneuil-sous-Biard, Tête peinte, stuc (dessin G. Fèvre, CEM).

\section{NOTES}

1.Sous la responsabilité de C. Sapin avec le soutien du Service régional de l'archéologie de Poitou-Charentes et la Société des Amis du musée de Poitiers.

2.Exposition au musée de Poitiers de septembre 2004 à janvier 2005 "Le stuc visage oublié de la sculpture médiévale", colloque 16-19 septembre 2004 "Stucs et décors sculptés de la fin de l'Antiquité au Moyen Âge (du V e au XII siècle)". 